\title{
脚気の原因に就いての研究 (続報)
}

福島医科大学小兒科学教室（主任 池田龍一教授）

池田龍一・徳富朝 光

\section{緒言}

脚気の原因少至原因の主体か： $\mathrm{V} \cdot \mathrm{B}_{1}$ 欠至で あるとの說は，今日一般に信しられてをる様 である。

抑々，この問題は, 多年に亘り, 多数の学 孝によつて，多歧多様に論議せられたもので あつて，これを大別する時には，大体次の三 說となる。即ち，

傳染哾，(Bael $z^{1)}$, Scheube, 青山 ${ }^{2)}$ ，三浦 $(\text { 讙 })^{3)}$, 緒方 $(\text { 正: })^{4)}$, 都贸 ${ }^{5)}$, 岡出及び小 久保(6), 稻垣 ${ }^{7)}$, 田中 ${ }^{8)}$, 樋 $\square^{9)}$, 松村 ${ }^{10)}$, 岡朴 ${ }^{11)}$ ，松川 ${ }^{12}$ 氏等）

中毒說，(榊 ${ }^{13}$ ，三浦（守） ${ }^{14)}$ ，長与 ${ }^{15}$ ，高

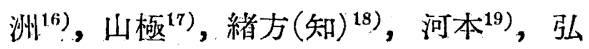
田 ${ }^{20)}$, 三宅 ${ }^{21)}$, 寺尾 ${ }^{22)}$, 照內 ${ }^{23)}$, 岡崎 ${ }^{24)}$, 後藤 ${ }^{25}$, , 佐藤 ${ }^{26}$ ) 氏等)

栄晨障碍說, (C. Eijkman ${ }^{27)}$, 島溒 ${ }^{28)}$, 大 森 ${ }^{29}$ 等)

の三大別となる。而して，之を詳に見れば， 今售その結論か得られてをるわけではなく， 一般的に信じられてをる $\mathrm{V} \cdot \mathrm{B}_{1}$ 欠乏說に対し ても，之に反对する学者が少加すある。そ の理由は, 病理解剖学的の面に於ても, 又, 臨牀の面に於ても，更に乳児脚気の面に於て も， $\mathrm{V} \cdot \mathrm{B}_{1}$ 欠泛說のみを以つてしては說明困 難なる事項が余りに多いからである。即ち，

〔I]病理解剖学的に見た脚気と V.B 攵之 症との相恭点は

1) 神経変化の相異 ${ }^{18) 30}$

2) 心巏所見の相異 ${ }^{15) 18) 28)}$

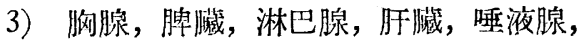
及び生殖腺の変化の相異 ${ }^{18) 28}$ )
4）血.液像の相異，特に淋巴球の增減の相 異 ${ }^{18 ）}{ }^{28)}$ ，並に塩基性顆粒を有する赤血球 の出現の有無 ${ }^{31)}$

5) 副腎所見の相異 ${ }^{18) 28)}$

6) 感染に対する抵抗力の相異 ${ }^{18)}$

7）出血性素因の有慜 ${ }^{18)}$

8）藏器に貯藏せられてをる $\mathrm{V} \cdot \mathrm{B}$ 量の测 定に於て, $\mathrm{V} \cdot \mathrm{B}$ 欠泛動物では $\mathrm{V} \cdot \mathrm{B}$ 量が 著明に減少してをるにも拘らす，脚気屍 臟器では, $\mathrm{V} \cdot \mathrm{B}$ 量が非脚気屍のそれに比 䎦して大差がない18)

〔II】臨状的に見た脚気と $\mathrm{V} \cdot \mathrm{B}$ 久乏症 と の相異点は

1）食欲及び消化障碍，並にそれに伴う栄 養状態の著しい相異. 即 $5, V \cdot B$ 次症 では顯著なる障碍が現れるが，脚気に於 ては，それが現れな(18)28)30)

2）脚気は，衆知の如く，青年に多くして， 老人及び小児に少く，又，夏から初秋に 加て多く，冬加ら春にかけて少い

3）脚気は，同一家族で同一食を攝る者の 間に於ても，羅患する者と然らさる者と がある28)34)35)

4）脚気患者は，運動不足者，殊に，坐業 もしくは同一位蜀在く保つて 仕事に従 事する者の闑に多(28)33)34)35)

5）脚気患孝の尿中，血中には，V· $\mathrm{B}_{1}$ 量か; 正常轮围內にある者が相当数あり ${ }^{36}$ 且つ， $\mathrm{V} \cdot \mathrm{B}_{\mathrm{l}}$ 火泛食を長期間投与しても脚気店 状を起さないものがある゙7)

〔III 乳览脚気の問題では

1）乳児脚気と果体との関係である。衆知 の如く，著明なる乳児脚気患览の母体に。 
臨牀上, 脚気症状を認め得ない様 な場合が往々ある。この様な洔に 断乳すれば（煉乳，或は 重湯の 如き $\mathrm{V} \cdot \mathrm{B}$ 含有量零に近きものに 代えても)，児体の脚気症状は例 外なく速に治る20334)35). 然も注目 すべき事は，斯る母親中の或者に 於ては，この断乳によつて，反つ て, 今艺現れていなかつた脚気症 状を現して来る者のある事であ

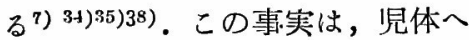
の断毒と母体への蓄㱴とを意味し てをる様に見えることであり，同 時に，乳児脚気と成人脚気とが一 元である事をも意味してをる様に

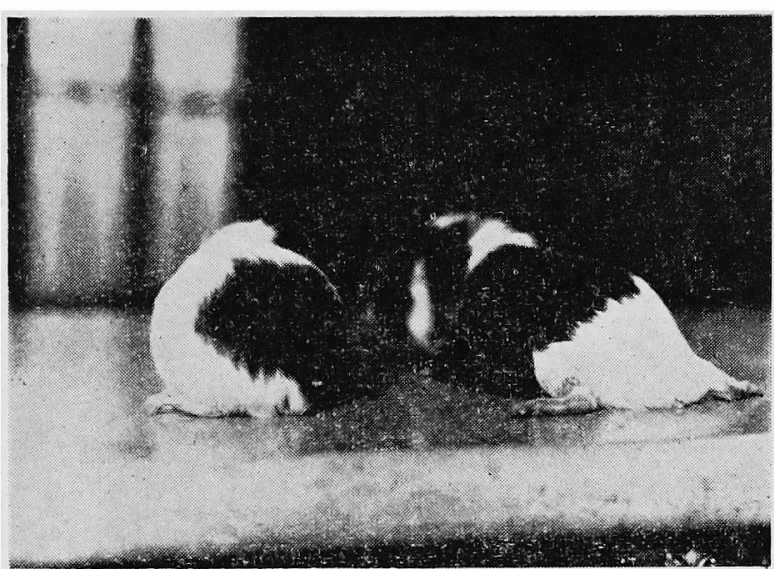

附図（1）右・濾液注射による脈瘵 左. 滤液注射直前に $\mathrm{V} \cdot \mathrm{B}_{1} 1 \mathrm{mg}$ 注射 （何れb洼射二時間後） 見える現象である。

2) 殼粉 $\left(\mathrm{V} \cdot \mathrm{B}_{1}\right.$ 殆零) 栄養障㥂児中, 乳児 脚気様症状を来すものは殆無いと言つて もよい程に極めて稀である ${ }^{34) 35)}$. のみな らす，純精白鞠粉のみによつては心娬の 肥大を惹起し難( 339740$)$

以上の如き譗事項を綜括する時には， $\mathrm{V} \cdot \mathrm{B}_{1}$ の欠圭というょりも，むしろ何物かの中毒を 思わせられる。それのみならす，沿崎 ${ }^{41)}$, 谷 $\square^{42)}$, 吳 ${ }^{43)}$ ，佐藤 ${ }^{26)}$ 氏等は乳児脚気母乳の 中に毒物の存在する事を認めて居る。

私共の一人池田 ${ }^{34}{ }^{35}$ は, 1924 年夏, V.B 火 そ說を以つてしては說明することの出来ない 集団脚気患者を経験し，これを出発点とした る健康成人に就ての人体実験に於いて, 過量 の耆た精白筂粉では容易に脚気が起るけれど も, 所謂第 1 会水炭素 (狹義の梼) では, V.B 零であるにも拘らす，（条件を等しくしても） どうても起らないことを知り, 更に進んで, 脚気患者に就て臨牀試験を行い, その結果,

消化遲鈍と腸内容の停滯 との二つか; 㑢気発症 に密接なる関係を持つらしき成續を得，これ に基きたる想定，即ち，「脚気毒の発生は，未

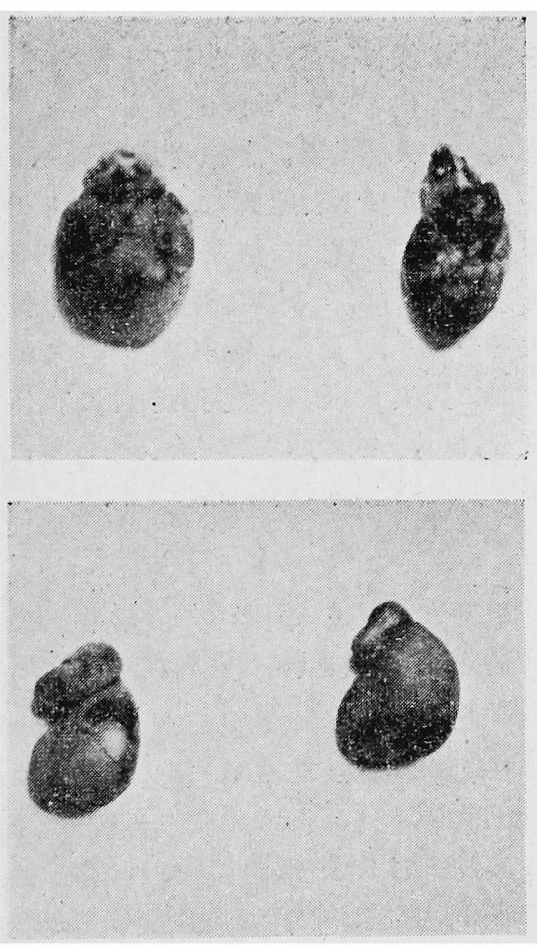

附図 (2)

上図 左 滤液泩射整海猽心（肥大） 右 同体重蜼康海猽心 右 同体重健康游㺍副紫
下図 左 滤液泩射整海㺍副督（肥大） 
糖化溦粉の腸內停渄に因るに非ざるか.」の想 定の下に，䊏白々米糊の自然應敗滤液，亚に， 档白々米糊玔ブイヨンを培地とする人备盲部 啺液の培養滤液地作り，各その舤菌なるもを 海溟の皮下に注射した。然る処，その海溟は游 痺状態となり，注射を続ける洔には摤れ，その

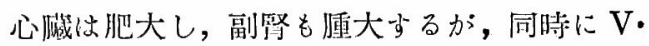
$\mathrm{B}_{1}$ 在注射する時には，これ等の埥作用は著し く緩和する事を認めた（附図 1 及2)。しかの みならす，この毒商生には次の如き条件の件 うことをも認めた，即ち，培地の䧈度がフル カリ性に近づき，グラム除性桿菌の貹殖良好

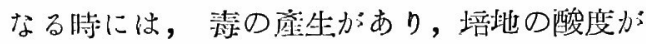
高まり, 球菌類の增殖良好となり，グラム陰 性桿菌の沙失する様な状態の時には，毒の网: 生加起らないということ，並にこの毒性は 三分間の㟟渄に耐光得ることをも認めて，之 を踤告して居る34) 35) 44).

私其の一人德富は, 殼粉栄養障碍児で乳児 脚気様症状を呈した症例に就いて，その食邻 を量的, 目つ, 質的に精查し, 乳児脚気梾店 状を来す為には，その食䬳に一定の条件があ ることを知り，更に，池田の指摘する測粉糊 加培地に発生する毒物の 発生条件に就いての 追究を行い，次の如き知見を得たので，それ 等の成績を以下項目別に記述する。

\section{I}

孚児脚気と区別困雖なる殼粉栄飤障 碍症児の症例（特にその㱏軨に就い

$\tau)$

款粉栄養障碍症に於て，極めて稀ではある か，乳児脚気と区别することの困踓なる症状，

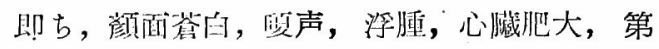
II 肺湩川脈音圥進, 腓反射の減退等老現し，而 も下湔を件わない者のある事は，つとに三 宅 ${ }^{45)}$, 長沢 ${ }^{46)}$ E等の記载があるが，広く注 目を浴びる様になつたのは，势和 4 年第 34 回 日朴小肾科学会に於て，太田孝之博士 ${ }^{47}$ 加款
粉栄養障碍症の乳児脚気型として 指摧し，

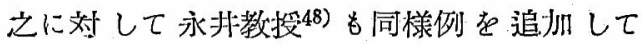
以来のことであつて，山本 ${ }^{49)}$, 泉田 ${ }^{50)}$, 大森

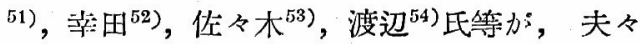
その臨牀例，並に，乳児脚気との間に於ける 病理組織学的比校等の落績を発表して居る。 然しながら，その食领を量的，目つ，質的に 充分なる調查老行つた街告は私基の調查範囲 內に於ては見当らぬ椂である。德富は福島医 大小児科を訲れたか了る症例 4 例に就いて， 之の食飭量的，質的に精查し，乳児脚気様 症状を起す為には，その食飭に一定の条件の 存在する事を認めた。

\section{[症例 1 ]}

\section{第 1 表}

\section{4月目男是}

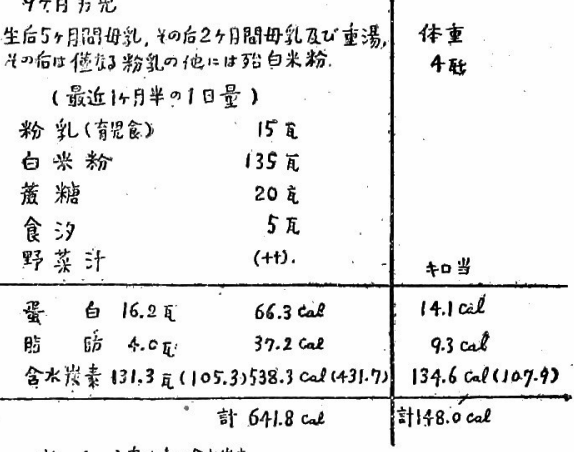

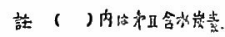

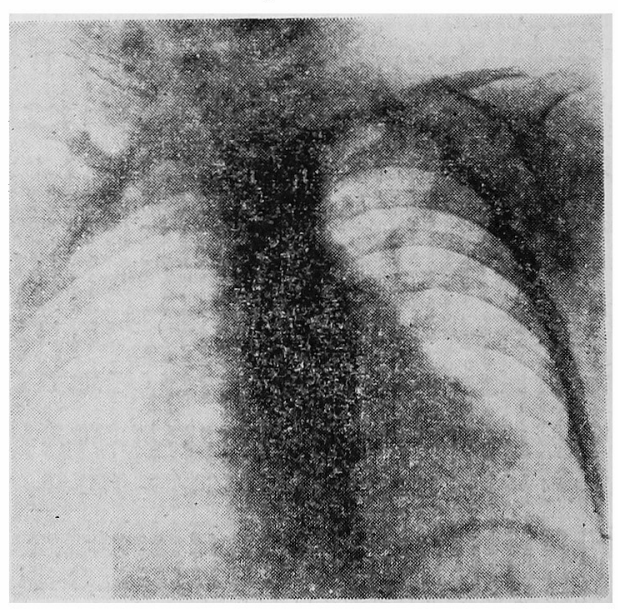

(管 1 䒾附図) 
即 b，第 II含水炭素小大部分を占由，第 I 含水炭素が極めて少い. 然しながら $\mathrm{V} \cdot \mathrm{B}_{1}$ は 野茶汁によつて可なりに補われてをつて，零 ではない。

\section{[症例 2]}

第 2 裴
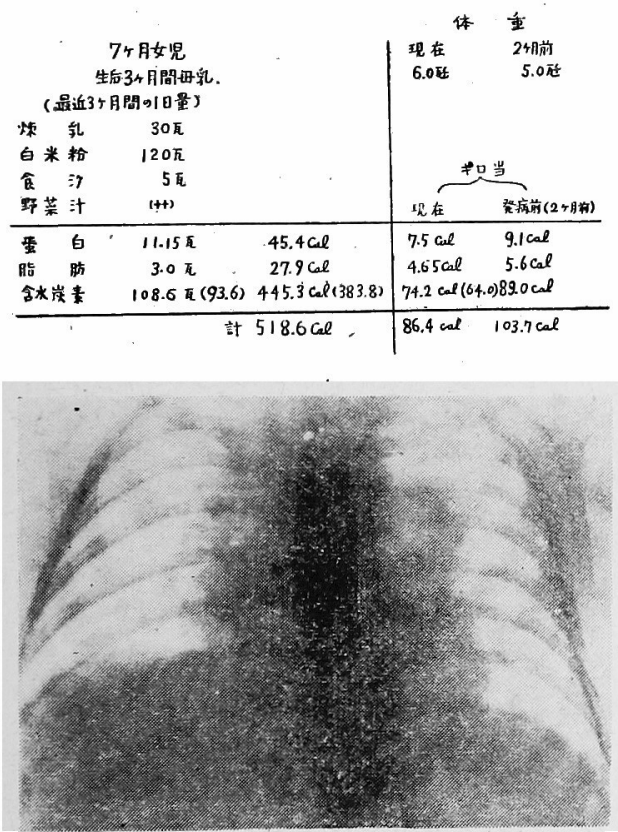

（第 2 表附図）

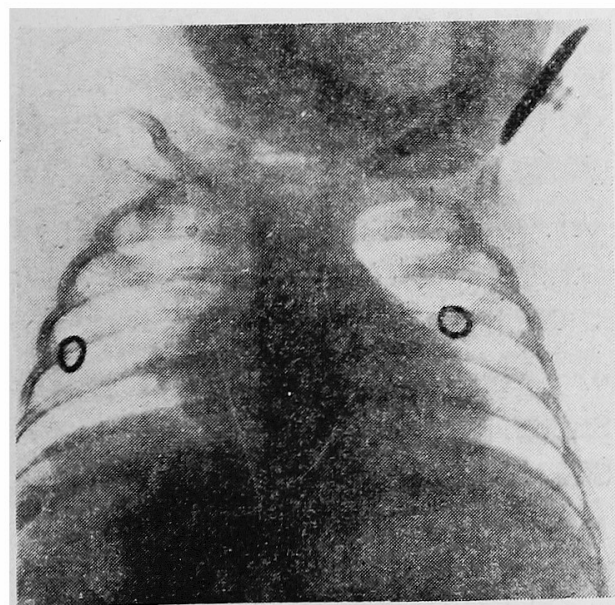

（第 3 表附図）
これも第II 含水炭素が大部分であつて，第 I 含水岸熬が極妙て少い。然しながら $\mathrm{V} \cdot \mathrm{B}_{1}$

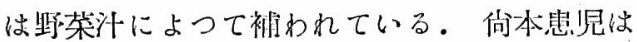
来院の 2 ヶ月前，乳児検診にょつて，飞の封 の体重か： $5 \mathrm{Kg}$ と制明して居るので，この壯 の体重にあてはめて見る持には，単位体重当 りの第 II 含水炭素か：一層の大量となつて居る 事がわかる。

\section{[症例 3 ]}

7ィ月男児

第 3 泰

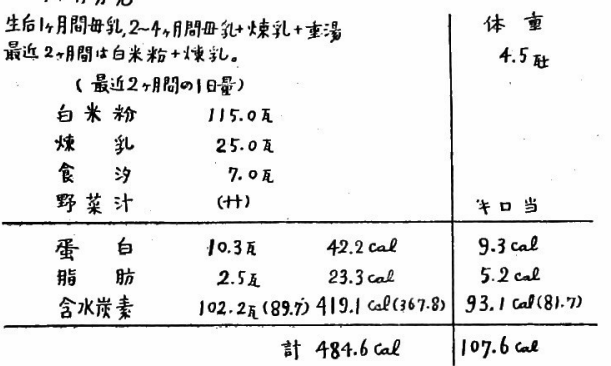

即古前 2 症例と同様に第 II 含水㷋素か：多く， 第 $\mathrm{I}$ 会水㷋素沙少く，V· $\mathrm{B}_{1}$ は野柴汁によつ て补われて居る。

\section{[症例 4]}

第 4 表

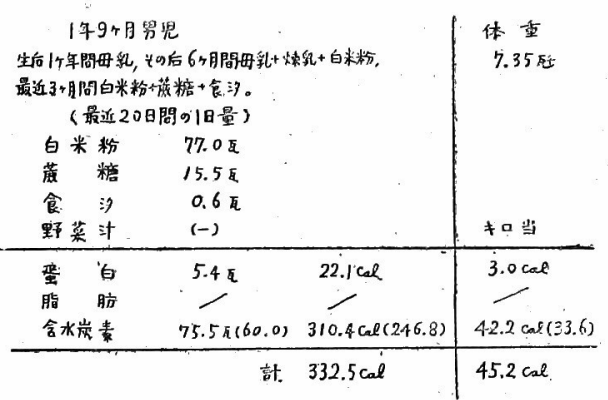

本症例は症状が極めて軽く，殊に心葴症状 は殆なく，たら゙四声があるのみで，乳児脚気 様と治言い缗好る程度であるか，前 3 者と比 䆥する上に意味があると考え附付加える。

即ち，前 3 者に比較して贪水炭素の攝取量 が大分少く，而も野茶汁を与光て居らす， $\mathrm{V} \cdot \mathrm{B}_{1}$ が零であるといつてもよい点が注目さ 
れる。

\section{小 括}

以上を要約する時には，乳児脚気様症状の 発現に対しては次の如き注目すべき条件のあ る事加知放る。

即ち,

1) 含水炭素の攝取量が皆だ大量である事

2) 而もその大部分は第II会水炭素であつ $\tau$ ，第 $\mathrm{I}$ 令水装素が閭題にならない程極 めて少量である事

3) $\mathrm{V} \cdot \mathrm{B}_{1}$ が零でないという雪

以上三つの悪柄を検討する睦には，次のこ とが考えられる。卯ち, 若し $\mathrm{V} \cdot \mathrm{B}_{1}$ が零であ つては全欲減退が著明となり，第一の条件で ある含水炭䋕の大量攝取が出来難くなる。こ の意㓇に於て V・B 件として大きな意義をもつて来るものと考え られる。 又, 第II 含水炭素が大量で第 I 含水 炭素が極妙て少量という事は，池田 ${ }^{34) 35)}$ 健 康成人に就いて行つた人体実験で 既に指摘し

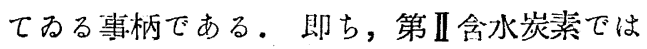
容易に脚気が起るけれども，第 I 含水炭素（狹 義の糖）では $\mathrm{V} \cdot \mathrm{B}_{1}$ が零であるにも拘らすど うしても脚気が起らないという事実に一致し て居る（この事は，実に，後迅する如く，腸 管內の酸度に重姴なる関係在持つ事柄と侾光

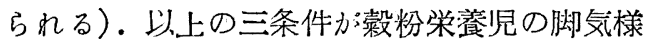
症状発症に対して大きな役割を演じてるる様 に臆测せられる。

\section{II}

粫白々米糊扣啠蛋白合成培地による 大腸菌滤液の乍性に就いて（その一）

箵言に於て毁に逃べた如く。池思は糊状淑

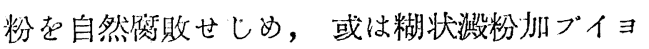
ンを培扡として人迴盲部腸液を培食して，そ
の滤液中に，海溟を麻痺させ，目っ，飞の心 䑏，亚に，副腎を肥大せしむる毒物の存する ことを垠告したが，その毒発生に就いての条 件を未だ充分に究明してるない，德富はこの 発生条件を究明せんとして次の実験を行つた。

\section{実験}

\section{I 実験動物及びその飼料}

体重 $10 \sim 15 \mathrm{~g}$ 迄の健康マウスを用いた。

飼料は第 5 表に示す如きものであつて，V・ $\mathrm{B}_{1}$ に就いては特別の㸡限を行はなかつた。

第 5 裴

飼料

1. 配合飼料

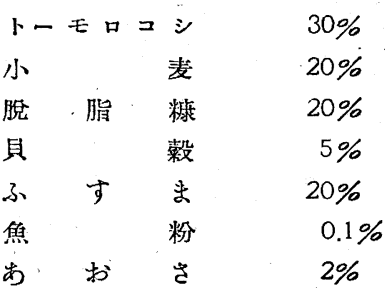

2. 野荣

（適当量）

3. 水

\section{II 実 験 方 法}

a）実験に使用しだ培地

塩化アンモン

$0.2 \%$

第一燐酸カリ

$0.1 \%$

第二料酸ソーダ

$0.6 \%$

硫酸第一鉄

$0.001 \%$

啃白々米粉

$1 \%$

以上の組成の合成培地（即ち，1\%精白々米 粉加無蛋白培地） 加熱滅菌し， $\mathrm{pH} 7.2 \sim 7.4$ として使用した。

b）実験に使用した菌種

Strepto-Kokken

Staphylo-Kokken (寺島株)

Entero-Kokken

Coli-Communior

Coli-Communis 
以上 5 種の菌に就いて，その各々を上述精 白々米糊含有無蛋白合成培地に $37^{\circ} \mathrm{C}$ に於い て, 2〜10 日間培養し，その培養液を洉紙にて 滤過し，その滤液を 4000 迴転 30 分間迮心し， その上液を採り，更に，之を 5 分間募沸隇菌 し，之をマウスの腹腔內に連日注射し，麻瘏 発現の程度及びその推移を観察した。

\section{| 実 験 成 綪}

\section{1. 対 称}

A）上述精白々米粉糊加筫蛋白培地 それ自 身を 10 日間 $37^{\circ} \mathrm{C}$ 町受卵器に放犆し, 前記の如 き方法を以つて滤液を作り，体重每瓦 $0.05 \mathrm{cc}$ 宛をマウスの腹腔內に注射したが，マウスは 注射前と同様にて，全く変化がなく，何等の 麻痺を認め得られず，且つ，剖検上に於ても 何等異常は認められなかつた。

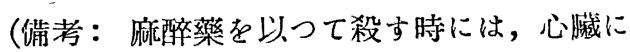
欝血を来して正碓なる心形を知り難 きを以つて瞬間的撲殺によつた.)

第 6 表

対称 (A)

精白々米粉加無蛋白培地そのるの了㴧液它注射 せるらの

$\begin{array}{ll}\text { 例 数 } & 8 \\ \text { 相 㾇 } & 0\end{array}$

B）次に精白々米粉を加えざる上述無蛋 白培地に既述 5 種の菌種を夫々加え 10 日間 $37^{\circ} \mathrm{C}$ に培養し，その滤液を夫々マウスの腹 腔內に体重每瓦 $0.05 \mathrm{cc}$ 宛注射したか，第 7 裴 の如く全例に磨痺を認めす, 且つ, 剖検上に 於ても何等異常所見が認められなかつた。

\section{第 7 表}

対称 (B)

無蛋白合成培地（精白々米粉を除く）の培養滤 液を注射せるるの

\begin{tabular}{|c|c|c|}
\hline 種 & 例数 & 尉波 \\
\hline Strept. K & 5 & 0 \\
\hline Staphylo. K & 5 & 0 \\
\hline Entero. $K$ & 5 & 0 \\
\hline Coli communior & 5 & 0 \\
\hline Coli communis & 5 & 0 \\
\hline
\end{tabular}

即ち，対称 A）及び B）の実験によつて, 次の事を確め得た。即ち。(1) 菌を玑えざる 精白々米粉糊加無蛋白合成培地を孵卵器中に 入れ置きたるもの，夫れ自身にはマウスを麻 瘏せしめる毒物は発生しない事，（2）精白々 米粉を除いた培地に於ては上述各菌種はマウ スを麻痺せしめる毒物を産生しない事.

\section{Strepto-Kokken 培䓹滤液の場合}

上述精白々米粉糊扣培地に Stredto-Kokken を培養し，培養日数 4 日，6日，10日の。 滤液を注射したか，第 8 裴の如く麻痺症状は 現れす，又，剖検上に於ても何等異変は認め られなかつた。

第 8 表 Strep-K 培養滤液注射

\begin{tabular}{|c|c|c|c|c|c|}
\hline $\begin{array}{l}\text { マウス } \\
\text { 番 是 }\end{array}$ & $\begin{array}{l}\text { 体重 } \\
(\mathrm{g})\end{array}$ & $\begin{array}{c}\text { 培盖日数 } \\
(\text { 日) } \\
\end{array}$ & $\mathrm{pH}$ & $\begin{array}{l}\text { 注射量 } \\
\text { (c.c.) }\end{array}$ & 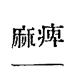 \\
\hline No. 1 & 12.0 & 4 & 6.8 & 0.6 & $=$ \\
\hline No. 2 & 13.2 & 4 & 6.8 & 0,65 & - \\
\hline No. 3 & 12.5 & 4 & 6.8 & 0.6 & - \\
\hline N.o 4 & 14.3 & 4 & 6.8 & 0.7 & - \\
\hline No. 5 & 10.5 & 6 & 6.4 & 0.5 & - \\
\hline No. 6 & 13.0 & 6 & 6.4 & 0.65 & - \\
\hline No. 7 & 11.0 & 6 & 6.4 & 0.55 & - \\
\hline No. 8 & 12.2 & 6 & 6.4 & 0.6 & - \\
\hline No. 9 & 12,5 & 10 & 6.4 & 0.65 & - \\
\hline No. 10 & 10.2 & 10 & 6.4 & 0.5 & - \\
\hline No.11 & 14.5 & 10 & 6.4 & 0.7 & - \\
\hline
\end{tabular}

3. Staphylo-Kokken 培養滤液の揚合 第9表に示す如く, Strepto-Kokken 培養 滤液の場合と同椂何等簧変は認められなかつ た。

\section{Entero-Kokken 塔食滤液の場合}

第 10 表に示す如く前二者と同様何等異変は 認められなかつた。

5. Coli-communior 培養滤液の場合

第 11 表の如く，培食日数か： 6 日以上で，而 もその時の培地の $\mathrm{pH}$ か; 6.6 以上の場合に, 
第 9 裴 Staphylo-K 培養滤液注射

\begin{tabular}{|c|c|c|c|c|c|}
\hline $\begin{array}{l}\text { マウス } \\
\text { 番 号 }\end{array}$ & $\begin{array}{c}\text { 体重 } \\
(\mathrm{g})\end{array}$ & $\begin{array}{c}\text { 培美日数 } \\
\text { (月) }\end{array}$ & $\mathrm{pH}$ & $\begin{array}{l}\text { 注射量 } \\
\text { (c.c.) }\end{array}$ & 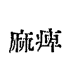 \\
\hline No. 1 & 10.0 & 4 & 6.8 & 0.5 & - \\
\hline No. 2 & 12.7 & 4 & 6.8 & 0.65 & - \\
\hline No. 3 & 10.5 & 4 & 6.8 & 0.5 & - \\
\hline No. 4 & $12: 2$ & 4 & 6.8 & 0.6 & - \\
\hline No. 5 & 13.0 & 6 & 6.6 & 0.65 & - \\
\hline No. 6 & 10.8 & 6 & 6.6 & 0.55 & - \\
\hline No. 7 & 11.5 & 6 & 6.6 & 0.6 & - \\
\hline No. 8 & 13.3 & 6 & 6.6 & 0.65 & - \\
\hline No. 9 & 10.5 & 10 & 6.6 & 0.5 & - \\
\hline No.10 & 12.5 & 10 & 6.6 & 0.65 & - \\
\hline No.11 & 12.2 & 10 & 6.6 & 0.6 & - \\
\hline
\end{tabular}

第 10 表 Entero-K 培養滤液注射

\begin{tabular}{|c|c|c|c|c|c|}
\hline $\begin{array}{l}\text { マウス } \\
\text { 番 号 }\end{array}$ & $\begin{array}{l}\text { 体重 } \\
(\mathrm{g})\end{array}$ & $\begin{array}{l}\text { 培美日数 } \\
\text { (日) } \\
\end{array}$ & $\mathrm{pH}$ & $\begin{array}{l}\text { 注射量 } \\
\text { (c.c.) }\end{array}$ & 麻序 \\
\hline No. 1 & $\overline{12.5}$ & 4 & 6.8 & 0.65 & - \\
\hline No. 2 & 13.5 & 4 & 6.8 & 0.65 & - \\
\hline No. 3 & 110 & 4 & 6.8 & 0.55 & - \\
\hline No. 4 & 12.3 & 4 & 6.8 & 0.6 & - \\
\hline No. 5 & 10.2 & 6 & 6.8 & 0.5 & - \\
\hline No. 6 & 14.7 & 6 & 6.8 & 0.7 & - \\
\hline No. 7 & 12.0 & 6 & 6.8 & 0.6 & - \\
\hline No. 8 & 11.5 & 6 & 68 & 0.6 & - \\
\hline No. 9 & 12.3 & 10 & 6.8 & 0.6 & - \\
\hline No.10 & 13.5 & 10 & 6.8 & 0.65 & - \\
\hline No.11 & 11.0 & 10 & 6.8 & 0.6 & - \\
\hline
\end{tabular}

その滤液をマウスに注射する時には，そのマ ウスは麻痺症状を現わして来る。培地の $\mathrm{pH}$ 值がそれよりも低值を是する際には，麻痺症 状の発現程度が軽微である。更に又, $\mathrm{pH}$ 值 が仮令高くとも，培䓹日数の短いものは，短 い程, 麻痺か溺いか，或は起らない，麻痺開 始時閪住, 早いものては, 注射後 5 分前後で あるか，一般には20〜30 分頃より初まる。そ の持続時間は 2 時間前後を境として 急激に恢 復して行くが，5時間媵も向正常に杘らない 例も見られた。

廂痺の程度を裴示するに当り，便宜上， $(H+H),(H),(+),( \pm)$ の四段階に分けて記 載し

（卅）は両下肢全く既痺して 步行殆不能の 程度
第 11 表 Coli communior 滤液注射

\begin{tabular}{|c|c|c|c|c|c|}
\hline $\begin{array}{l}\text { 番 舀 } \\
\end{array}$ & $\begin{array}{l}\text { 体重 } \\
(\mathrm{g})\end{array}$ & $\begin{array}{l}\text { 培美日 } \\
\text { 数(日) }\end{array}$ & $\mathrm{pH}$ & $\begin{array}{l}\text { 注射周 } \\
\text { (c.c.) }\end{array}$ & 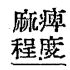 \\
\hline No. 1 & 13.0 & 2 & 7.2 & 0.65 & - \\
\hline No. 2 & 11.2 & 2 & 7.2 & 0.55 & - \\
\hline No. 3 & 12.0 & 2 & 6.8 & 06 & - \\
\hline No. 4 & 10.5 & 2 & 6.6 & 0.5 & - \\
\hline No. 5 & 13.2 & 2 & 6.6 & 0.65 & \pm \\
\hline No. 6 & 10.5 & 4 & 6.8 & 0.5 & + \\
\hline No. 7 & 11.5 & 4 & 6.8 & 0.55 & + \\
\hline No. 8 & 10.0 & 4 & 6.8 & 0.5 & $H$ \\
\hline No. 9 & 13.0 & 4 & 6.8 & 0.65 & $H$ \\
\hline No. 10 & .10 .5 & 5 & 6.4 & 0.5 & + \\
\hline No.11 & 11.0 & 5 & 6.8 & 0.55 & $\mathrm{Ht}$ \\
\hline No. 12 & 11.5 & 6 & 6.0 & 0.55 & - \\
\hline No.13 & 10.5 & 6 & 6.6 & 0.5 & - \\
\hline No. 14 & 10.0 & 6 & 6.6 & 0.5 & \pm \\
\hline No, 15 & 12,5 & 6 & 6.6 & 0.65 & + \\
\hline No. 16 & 12.5 & 6 & 6.6 & 0.65 & + \\
\hline No.17 & 12.2 & 6 & 6.2 & 0.6 & + \\
\hline No. 18 & 12.0 & 6 & 6.6 & 0.6 & Ht \\
\hline No, 19 & 12.0 & 6 & 6.8 & 0.6 & H \\
\hline No.20 & 12.5 & 6 & 6.6 & 0.65 & $\mathrm{Ht}$ \\
\hline No. 21 & 10.3 & 6 & 7.0 & 0.5 & $\mathrm{Ht}$ \\
\hline No. 22 & 10.3 & 6 & 7.0 & 0.5 & $\mathrm{HH}$ \\
\hline No. 23 & 11.0 & 6 & 7.0 & 0.55 & Ht \\
\hline No. 24 & 10.0 & 7 & 6.0 & 0.5 & \pm \\
\hline No. 25 & 13.0 & 7 & 6.2 & 0.65 & - \\
\hline No. 26 & 10,5 & 7 & 6.2 & 0.5 & + \\
\hline No.27 & 10.3 & 7 & 6.2 & 0.5 & + \\
\hline No. 28 & 12.2 & 7 & 6.2 & 0.6 & $\mathrm{Ht}$ \\
\hline No. 29 & 13.0 & 7 & 6.2 & 0.65 & + \\
\hline No.30 & 12.0 & 7 & 6.2 & 0.6 & + \\
\hline No.31 & 13.0 & 10 & 5.4 & $0: 65$ & - \\
\hline No.32 & 13.0 & 10 & 5.4 & 0.65 & - \\
\hline No.33 & 10.7 & 10 & 5.4 & 0.55 & \pm \\
\hline
\end{tabular}

（H）は腰を全く下げて這う様に腹部をひ さづつて步く程度

（十）虫腰を一下げてよたよた步く程度

（土）は正常のものに比較して㛎を低く下 げて步行敏連を欠く程度

とした。

即ち, Coli-Communior 培養滤液を注射し たマウス 33 例に施ては，

$\left.\begin{array}{rr}(H) & 8 \text { 例 } \\ (+H) & 2 \text { 例 } \\ (+) & 10 \text { 例 }\end{array}\right\} 20$ 例




$$
\left.\begin{array}{ll}
( \pm) & 4 \text { 例 } \\
(-) & 9 \text { 例 }
\end{array}\right\} 13 \text { 例 }
$$

であつて，（土）及び（一）の13 例は培地の $\mathrm{pH}$ が酸性に傾いて居るか，或情養日数の 短いものであった。

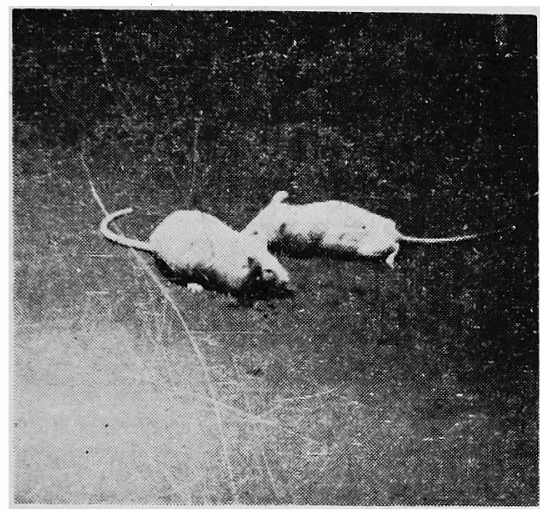

附図 (3) 左 正常マウス

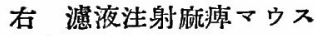

この毒力の强い滤液を每日 2 3 回宛漸次增 量してマウスに注射する時には，そのマウス は2〜4 日にして整れる。これを剖検してみれ ぱ下図の如くその心臟の肥大してるる事が認 められる。

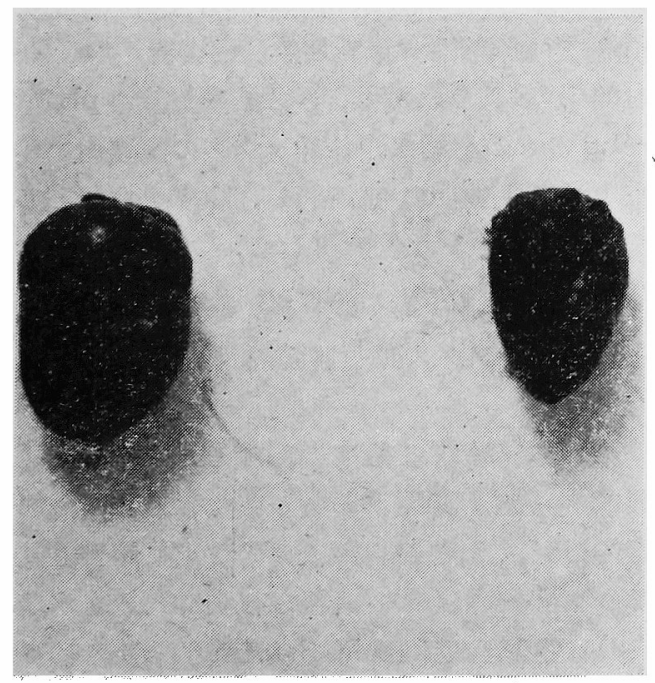

附図（4）左 滤液泩射屍心 右 同体重健康心

\section{Coli-communis 培食滤液の場合}

第 12 裴 Coli communis 源液注射

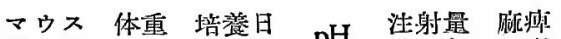

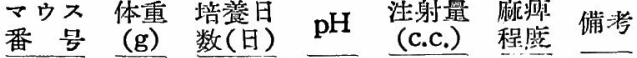
$\begin{array}{llllll}\text { No. } 1 & 10.0 & 2 & 7.2 & 0.5 & -\end{array}$ No. $2 \quad 12.3 \quad 2 \quad 7.2 \quad 0.6 \quad \pm$ No. $3 \quad 12.0 \quad 2 \quad 6.8 \quad 06 \quad-$ $\begin{array}{llllll}\text { No. } 4 & 11.3 & 2 & 6.8 & 0.55 & -\end{array}$ $\begin{array}{lllllll}\text { No. } 5 & 14.0 & 2 & 6.6 & 0.7 & -\end{array}$ $\begin{array}{llllll}\text { No. } 6 & 12.7 & 4 & 6.8 & 0.65 & \text { H }\end{array}$ $\begin{array}{llllll}\text { No. } 7 & 11.2 & 4 & 6.8 & 0.55 & \text { H+ }\end{array}$ $\begin{array}{lllllll}\text { No. } 8 & 13.5 & -4 & 68 & 0.7 & \text { H }\end{array}$ $\begin{array}{lllllll}\text { No. } 9 & 12.2 & 4 & 6.8 & 0.6 & -\end{array}$ $\begin{array}{lllllll}\text { No.10 } & 12.0 & 4 & 6.6 & 0.6 & \mathrm{HI}\end{array}$ $\begin{array}{lllllll}\text { No.11 } & 12.0 & 5 & 6.8 & 06 & \text { Ht }\end{array}$ $\begin{array}{lllllll}\text { No.12 } & 11.5 & 5 & 6.4 & 0.55 \quad \text { Ht } & \text { 死亡 }\end{array}$ $\begin{array}{llllll}\text { No.13 } & 11.5 & 5 & 6.2 & 0.55 & -\end{array}$ $\begin{array}{llllll}\text { No.14 } & 12.5 & 6 & 6.8 & 0.6 & \text { H }\end{array}$ $\begin{array}{llllll}\text { No.15 } & 13.0 & 6 & 6.8 & 0.65 \quad \text { H }\end{array}$ $\begin{array}{lllllll}\text { No.16 } & 12.5 & 6 & 6.8 & 0.6 & \text { HI }\end{array}$ $\begin{array}{llllll}\text { No.17 } & 13.0 & 6 & 6.8 & 0.65 & \text { HH }\end{array}$ $\begin{array}{llllll}\text { No.18 } & 12.5 & 6 & 6.8 & 0.6\end{array}$ $\begin{array}{llllll}\text { No.19 } & 12.2 & 6 & 6.8 & 0.6 \quad+\end{array}$ $\begin{array}{lllllll}\text { No.20 } & 10.5 & 6 & 6.8 & 0.5 & \text { H }\end{array}$ $\begin{array}{lllllll}\text { No.21 } & 11.0 & 6 & 6.8 & 0.55 \quad \text { H }\end{array}$ $\begin{array}{lllllll}\text { No.22 } & 10.5 & 6 & 6.4 & 0.5 & \text { Ht }\end{array}$ $\begin{array}{llllll}\text { No.23 } & 11.0 & 6 & 6.4 & 0.55 & +\end{array}$ $\begin{array}{llllll}\text { No.24 } & 13.0 & 6 & 6.4 & 0.65 & \text { - }\end{array}$ $\begin{array}{llllll}\text { No.25 } & 13.0 & 6 & 5.0 & 0.65 & -\end{array}$ $\begin{array}{lllllll}\text { No.26 } & 12.1 & 7 & 6.8 & 0.6 & \mathrm{Ht}\end{array}$ $\begin{array}{lllllll}\text { No.27 } & 12.0 & 7 & 6.8 & 0.6 & \text { HI }\end{array}$ $\begin{array}{lllllll}\text { No.28 } & 14.7 & 7 & 6.8 & 0.75 & \text { Ht }\end{array}$ $\begin{array}{lllllll}\text { No.29 } & 12.3 & 7 & 6.8 & 0.6 & \mathrm{HH}\end{array}$ $\begin{array}{llllllll}\text { No.30 } & 12.0 & 7 & 6.8 & 0.6 & \text { H }\end{array}$ $\begin{array}{lllllll}\text { No.31 } & 12.5 & 7 & 6.8 & 0.6 & \text { H }\end{array}$ $\begin{array}{lllllll}\text { No.32 } & 15.3 & 7 & 6.8 & 0.75 \quad \mathrm{Ht}\end{array}$ $\begin{array}{lllllll}\text { No.33 } & 13.6 & 10 & 6.4 & 0.65 & -\end{array}$ $\begin{array}{llllll}\text { No.34 } & 14.3 & 10 & 6.4 & 0.7 & - \\ \text { No.35 } & 11.0 & 10 & 6.4 & 0.55 & -\end{array}$

第 12 韭に示す如く，前倠 (Coli-communior 墙養滤液) の場合と同様に腑痻走来し，心 臟肥大を来す。（勿論この埸合も，培䓹日数 6 日以上で, 且つ, $\mathrm{pH6.6}$ 以上の皆合に於ては 例外なく症状か特に强く現れて来る.)

即ち, Coli-communis 培養源液を注射した マウス 35 例の內訳は 


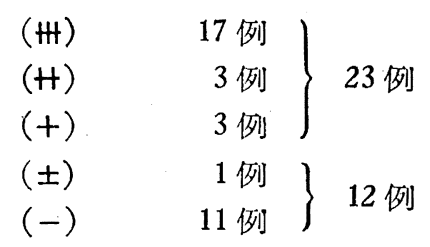

であつて，(土）及び（一）のもの 12 例は $\mathrm{pH}$ が酸性に傾いて居るか，或は培養日数の短い ものであつた。 叉，この毒打の强い浪液は Coli-communior 培養滤液の場合と同椂, マ ウスの心缄を肥大せしめる。即ち，総てに於 $\tau$ Coli-communior 培養滤液の皆合と殆同様 であつた。

$$
\text { 小 括 }
$$

以上の如く, Strepto-Kokken, StaphyloKokken, Entero-Kokken, Coli-communior 及び Coli-communis の 5 種の菌を耪白々米 粉糊加無蛋白合成培地に培養し，之の無菌滤 液をマウスに注射して，麻痺発現亚にその推 移に就いての観察を行つた。

その結果, Strepto-Kokken, StaphyloKokken, Entero-Kokken の 3 種のもの了培 養滤液はいすれもマウスに対して 何等の影響 を及ぼさなかつた。然し，Coli-communior 及び Coli-communis の 2 種の培養滤液はマ ウスを痳痺させ，その心藏を肥大せしめた。 但し，その時の培地の $\mathrm{pH}$ か酸性に傾いて居 る様な場合，或は，酸性に傾かなくとる，培 養日数が甚げ短い場合には，麻痺は来ないか， 来ても極く軽い程度であり，又心臟肥大も㙷 著には現れない。即ち, 培地の $\mathrm{pH}$ がテルカ リ性に傾いてるて而も培養日数か：長ければ長 い程，その滤液の素性は强い様な結果を示し た。

粘白々兆糊加且蛋白合成培地による 大腸菌滤液の毒性に就いて（その二）

精白々米糊州焎蛋白合成培地の $\mathrm{pH}$ がフル
カリ性に傾いてるる条件の下に於て，Colicommunior 及び Coli-communis が之れに 倒く時には，その培養液の中に，マウスを斾 痺させ，且つ，その心臟を肥大せしむる毒物 か﨎生される事，韭に，他の球菌類を以つて してはこの毒物の髉生がない事を前章に於て 述べた。本章に於ては，該清物の性:状を知ら んと欲して行つた実験, 即ち，健康マウス， 肝障碍マウス，㫫に， $\mathrm{V} \cdot \mathrm{B}_{1}$ 欠乏鸰食マウス に，夫々この奨物を注射して得た処の結果に 就いて記述する。

\section{実験 \\ I 実験動物及び飼料は第二章と同様}

但し $\mathrm{V} \cdot \mathrm{B}_{1}$ '况食飭としては次のものを用 いた。即ち，精白々米粉を $120^{\circ} \mathrm{C}, 12$ 時間加 熱乾燥して，V.B の肝油を添加して与えた ${ }^{55)}$. 又，肝障碍には 四塩化炭素を朋い，その $30 \%$ \%オーブ油溶液 $0.05 \mathrm{cc}$ を，予め実験前 3 日間，1日 1 回腹腔 內に注射した ${ }^{56)}$.

\section{II 実 験 方 法}

第二章に於て行つたと同様に，健康人篹 ょり分離した Coli-communior, Coli-communis t $1 \%$ 精白々米糊加無蛋白合成培地に 10 日間 $37^{\circ} \mathrm{C} に て$ 培養し，その無菌滤液中 $\mathrm{pH} 6.8$ 〜7.0のものを選び，各群マウスの腹腔內に体 重 1 瓦当り $0.05 \mathrm{cc}$ 宛注射し, 腑痺を目標とし て，その成續を比較検討した。

\section{III 実 験 成 縤}

1）健康マウス群と肝障障マウス群との 比較

第 13 裴の如く，肳痺の程度及びその持続時 間は，共に肝障㥂群の方が强くこの滤液の 素作湖か，旰に於て可成りの程度に解毒され てるる紫を示してるる様に思われる。

2）健康マウス中 $\mathrm{V} \cdot \mathrm{B}_{1} 0.1 \mathrm{mg}$ 注射群と

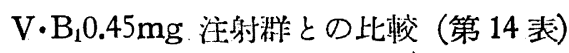

健康マウス湴を二群に分ち，一方には V. 
第 13 裴 健康マウス群

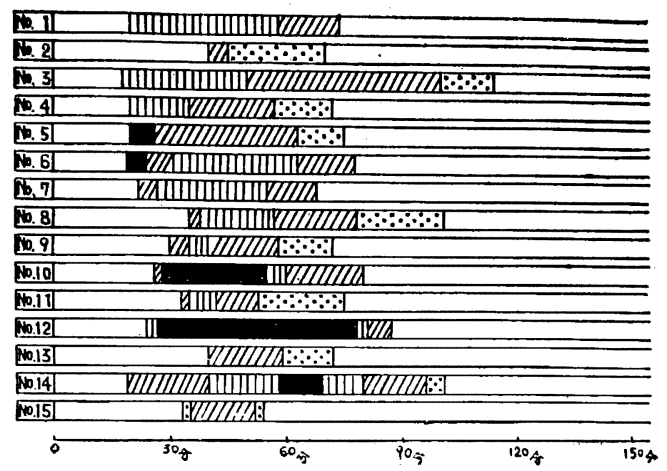

肝 障 碍 群

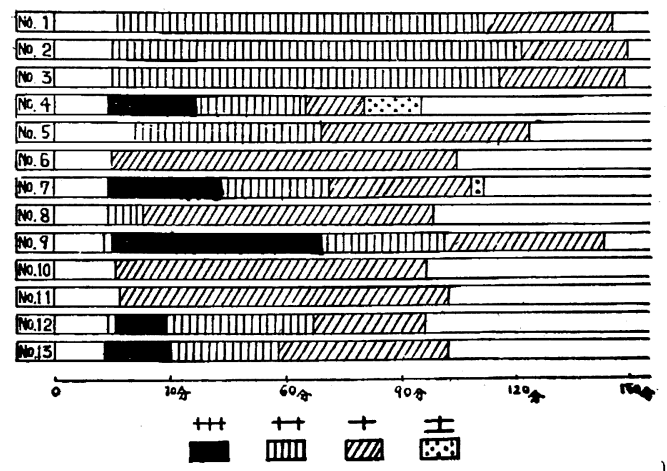

$\mathrm{B}_{1} 0.1 \mathrm{mg}$ ，他方には $\mathrm{V} \cdot \mathrm{B}_{1} 0.45 \mathrm{mg}$ 注射を行い， 30 分後に Coli-communior 培養滤液を注射 した所, $\mathrm{V} \cdot \mathrm{B}_{1} 0.45 \mathrm{mg}$ 注射群は $\mathrm{V} \cdot \mathrm{B}_{1} 0.1 \mathrm{mg}$ 注射群に比して腑痺を来すもの少く，且つ，
その程度も軽く恢復も早かつた。即ち, $\mathrm{V} \cdot \mathrm{B}_{1}$ の量が多ければ多い程麻痺は起りにく了, 又, 起つてもその程度が軽いことを示してをる様 に思われた（第 14 表）.

3）朋障碍マウス群中 $\mathrm{V} \cdot \mathrm{B}_{1} 0.45 \mathrm{mg}$ 注射

群と $\mathrm{V} \cdot \mathrm{B}_{1} 0.45 \mathrm{mg}$ 注射群との比較

予め四塩化炭素によつて 肝障碍を起させて をるマウス群を二群に分け，一方にはV·B $0.1 \mathrm{mg}$ ，他方には $\mathrm{V} \cdot \mathrm{B}_{1} 0.45 \mathrm{mg}$ を夫々注射し， 30 分後に Coli-communior 培養滤液を注射 した。 $\mathrm{V} \cdot \mathrm{B}_{1} 0.45 \mathrm{mg}$ 注射群は明らかに $\mathrm{V} \cdot \mathrm{B}_{1}$ $0.1 \mathrm{mg}$ 注射群に比し，䇢痺か起り難く，その 程度も軽度であつた．この事は $\mathrm{V} \cdot \mathrm{B}_{1}$ の解毒 作用が肝を通しての解毒以外に， $\mathrm{V} \cdot \mathrm{B}_{1}$ それ 自身が直接的に，この表物を中和してるる事 を示してをる様に思われる (第15 表).

4） $\mathrm{V} \cdot \mathrm{B}_{1}$ 尔无食飼育、ウス群と肝障碍 マウス群との比較

$\mathrm{V} \cdot \mathrm{B}_{1}$ 欠泛食で 10 日閶䋒育を行い，未だ $\mathrm{V} \cdot \mathrm{B}_{1}$ 欠乏症としての俯痺を来さざるマウス 群と肝障碍マウス群との二者に就いて，各ふ Coli-communior 培養滤液を注射して比較し て見た。

$\mathrm{V} \cdot \mathrm{B}_{1}$ 欠泛食鸰育マウス群は前述のいづれ のマウス群よりも, 即ち, 肝障碍マウス澼よ りも，明らかに强度の症痺を現し，而もその 持続時間も長い。これは $\mathrm{V} \cdot \mathrm{B}_{1}$ の中和機序が
$\mathrm{V} \cdot \mathrm{B}_{1} 0.1 \mathrm{mg}$ 注射

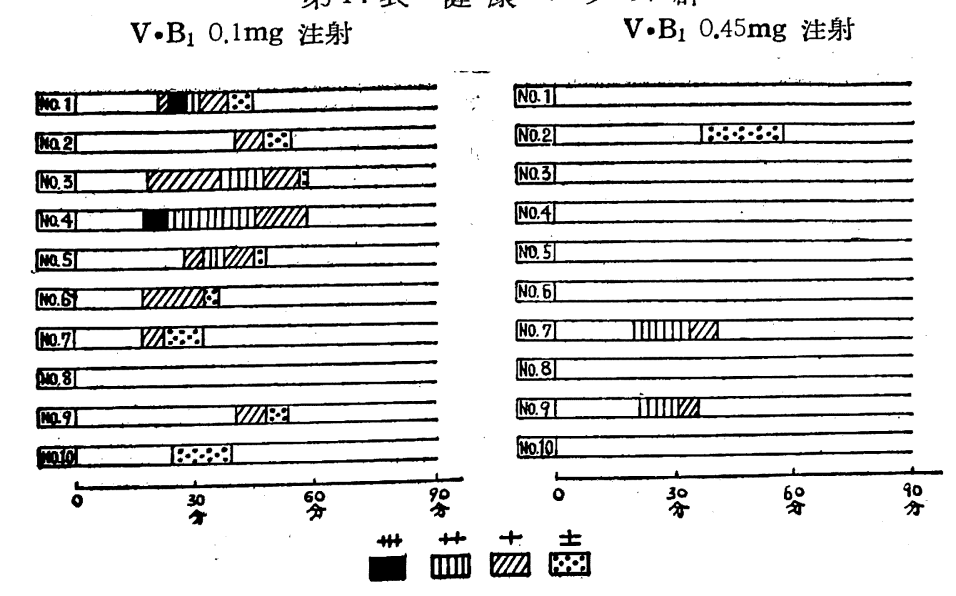

第 14 裴健康マウス群 
第 15 表，肝 障 碍 群

$\mathrm{V} \cdot \mathrm{B}_{1} \quad 0.1 \mathrm{mg}$ 泩射

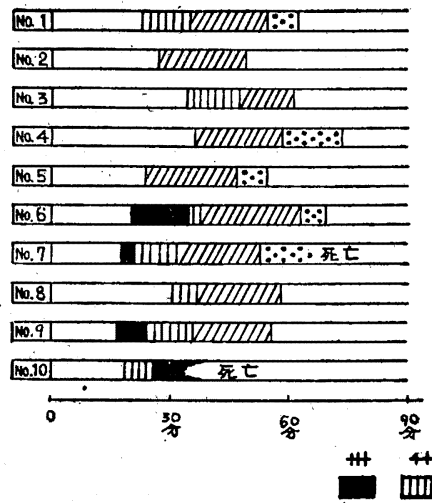

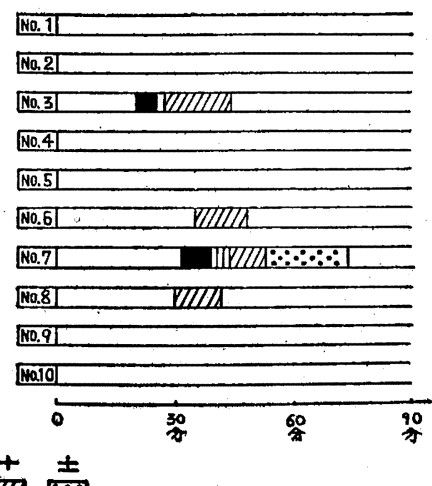

小

括

以上の成績を小括すれば次の如くなる。

1）麻痺症状の最も烈しく現れたものはV・ $\mathrm{B}_{1}$ 欠乏食飼育マウス群であって，これに次ぐ のが肝障碍マウス群であり，最も軽度のもの が健康マウス群であつた。

2）予め $V \cdot B_{1}$ の注射を受けてをるマウス に於ては，健康マウス群に於ても，肝障碍、 ウス群に於ても， $\mathrm{V} \cdot \mathrm{B}_{1}$ の注射量に比例して 麻痺症状の軽いことが見られる。

3）この濾液の毒作用は肝によつても，亦， $\mathrm{V} \cdot \mathrm{B}_{1}$ 自体によつても中和せられ，然も， $\mathrm{V} \cdot \mathrm{B}_{1}$ 体自の中和作用の方がより强力である 様に思われる成績を示した。

份，Coli-communis の培養滤液に於 $\tau$ 同 様の成績が得られた。

\section{考按}

(1)

緒言に於て述べた如く，池田 ${ }^{34}$ 35) $^{35}$ の人体実験 に於ては，第 II 含水炭素の過量投与によつて， 容易に琺気症状を発現せしめ得たか，第 I 含 水炭素を以つてしては $\mathrm{V} \cdot \mathrm{B}_{1}$ が零なるにも拘 らす，どうしても脚気症状が起らなかつた。

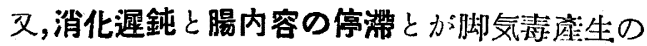


好条件を作ると考えられる成績をも得てをる。 更に，この第一章に於て述へた如く，軖粉栄䓹 障碍児中稀に見る乳児脚気样症（菊粉栄養障 碍症の乳児脚気型）に於ては，その発現条件 として (1)第 II 含炭素の大量攝取，(2)第 I 含炭 素攝取量の極めて小, (3) $\mathrm{V} \cdot \mathrm{B}_{1}$ 攝取量が零な らざることの三条件が不可欠の荘素である。

これ等の諧事項を綜合すれば，脚気症発現 に対して，次の事か物語られてるる様に考え られる。即ち，

1）難醱酵性（従つて腸內酸度難上昇性） の所謂第 II 含水炭素（潩粉）の大量摂取 や,

2）消化遅鈍，腸內容の停滯は些に毒意生 の好条件となり，

3）易醴酵性（従つて腸內酸度易上昇性） の所謂第 I 含炭素（狹義の糖）の攝取 は毒產生の悪条件となる事を示してをる様 に考えられる。

更に，第二章に於て述べた如く，造表菌は Coli-communior 及び Coli-communis であ つて，その造毒環境はアルカリ性に傾く場所 に於て，糊状測粉の存在かなければならな い.

以上の諸事項を基礎として，脚気発病の機 序を考按する時には次の如く考えられる。

先づ乽た精白測粉の偏食（第 I 含水炭素及 び脂肪の小食）によつて腸內酸度の低下を来 し, Coli-communior, Coli-communis の賭 殖造毒に対する好条件を作る。この場合，攝 取精白淑粉の量か， その人の必需量を越えた ク，或は，その人のその時の消化力以上に及 んで，その過剩量が未分解の睢に，種々なる 条件によつて，腸內に停滯する時には，その 過剩量と停溲時間とに比例して毒の発生が起 るものと考元られる.白米飯大食者と雖も, 運動量大なる者は罹患せす，さまで大食では なき者と雖も，運動不足者纴至坐業者力;罹患 し易き理由も此処にあると侾えられる。
ころに非常に注目すべき事柄は昭和 3 年干

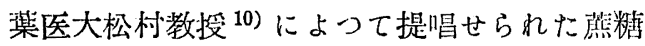
分解性大腸菌，所謂松村脚稫菌の問題である。 氏によれば「脚気菌は実験的鳥類脚気の腸管 內に䅞常発見せられ，又，人類脚気患者の大 多数に於て疾患経過の一定時期に揫便中ょり 検出せられ，而も非脚気省，非脚気動物では 脚気患者の如く高率には発見せられす， 又， この菌を経口的に投与する㭙には該動物は脚 気症状を来し，之の血清は該菌と特異的凝集 反応を示し, 且つ, 該菌の一定濃度浮遊液の 皮下注射に対し，脚気患者は特巽アレルギー を示す.」と言い, 該菌を以つて脚気の伝染說 を主張した事は衆知の通りである。然しなか～ ら, 岡本 ${ }^{57)}$, 岩崎 ${ }^{58)}$, 有山 ${ }^{59)}$, 塩沢 ${ }^{60)}$, 矢野 ${ }^{61)}$ ，衣川 ${ }^{62)}$, 橋本 ${ }^{63)}$, 大野 ${ }^{64)}$ ，圾本 ${ }^{65)}$ 等の訬 氏によつて施行せられた追試の結果を綜合す れば, 該菌を以つて脚気病原菌と見做し得す, 寧乃 Coli-communior に属する大腸菌（松村 菌)か之等疾患に際し随件的に多数出現する。 のであろうとの見解をとり，所謂脚気菌の存 在すら疑われてをる。私共の実験に於て，未糖 化第II 含水炭素(白米糊)を培地としたる堭合， Coli-communior 及び Coli-communis か脚 気発生に主要なる役割を演してるる事実に徵 し，松村教授の所謂脚気、菌說は第】念水炭素 (淑粉糊) の存在の下に於ては，全く理由な き事ではない様に考元られる。即ち，白米偏食 (第 $\mathrm{I}$ 含水炭素及び脂肪の小食)，によつて腸內 酸度の低下を来し，延いて Coli-comunior の 繁殖を来す時に，未来分解の測粉糊か;存在する ならば，毒產生が成立するわけである。

\section{考按}

(2)

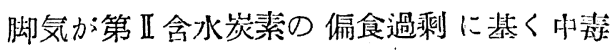
であるとすれば， $V \cdot B_{1}$ 欠恶說では說明し得 られない数々の事項が容易に說明し得られる 様に思う。即古， 
1）脚気の罹患か：夏季に多いのは，次の如 く考えられる。夏季に於ては，暑熱の為 に個体の消化力，解表力が共に低下して 中請を起し易くなるのみならす，腸管內 の $\mathrm{pH}$ が冬季よりもアルカリ性に傾き易 く，又，大腸菌属も多種多数となり ${ }^{66)}$, 延いて，毒物の斑生も容易になると考え られる。

2）脚気が老人や小韭に少く，青年に多い ことに就いては次の如く侾えられる。

1）老人は一般に小食であつて，第II 合 水炭素の排取量も少く，従つて毒源と なり得るもの了攝取が少い為であろう。 稀に見る老人脚気患者か心づれも運動 不足者であり，且つ，白米飯大食者で あるのを見ても，この軎加漞われる。

口）小児は，たとえ第II含水炭素の大量 を摴取しても，元来必需量が大であり， 且つ，一般に遊び迴つて運動量も大で ある為に過剩の未糖化第 II 含水岑素か; 消化管內に停滯し難い，しかのみなら す，大人に比して，菓子類等にょる第 I 合水炭素の 攝取量か; 比槙的大量であ る.その為に腸管內の $\mathrm{pH}$ は酸性に傾 き易く, 従つて, 造毒菌の繁殖も起り 難いものと考えられる。

八）青年，特に，机に向う学生や坐㗬に 携る者の間に脚気䍜患か：多いのは，青 年は一般に大食であり，殊に，これ等 羅患青年は一般に副食物（殊に脂肪） の攝取量力:少く，第 II 会水炭素の攝取 量のみか;偏頗的に大となり，その為， 腸管內の酸度か; 低下して 造毒菌の增殖 が容易となる．斯る条件にある者か， 勉学や坐業 その他の為に運動量不足と なり，一層の過剩未桾化糊の停滯とな り，その結果，埥諘生が容易となるも のと思われる。

）手術後, 或は急性伝染病の恢復期,
率㷌等に朋気の発生し易き事も,軟く者 た白米偏食に上る腸管內の酸度低下と，

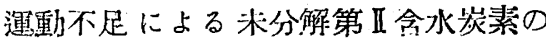
腸內停滞との二つが毒率生の好条件に なるものと考えられる。

3）同一家族に於て同一食をとる者の間に 於て，脚気に罹患するものと然らざる者 とのある事に就いては次の如く考光られ る．同一食と言つても，各人の白米飯攝 取量, 運動量, 消化力の程度, 解求能力 の程度等には個人的に前異があつて一様 でない，故にこの事は当然の事と考えら れる。

4）玄米飯食か脚気の治療に例外なき卓効 を奏する理由に就いては，次の如く考光 られる。第一に立米飯は大食出来ない。 即ち，表源となり得る物の量が少い．第 二には，玄米の有する $\mathrm{V} \cdot \mathrm{B}$ の解跧作朋 と玄米瀻維による腸蠕動促進に附随する 停帮防止とであり，第三には，棣成分の

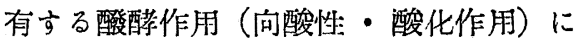
よる腸內酸度の上昇が考えられる。鮭新 然の上等を作るには，食塩の量を減して 䯙味を少くする。然し，只減塩しただけ では隽敗（向アルカリ性：還元作用）を 起すを以つて，その減壏の代りに米糠を 加入し，この米栤の醱酵作用によつて腐 敗を防止してをる。これを見ても，米栤 の醴酵作用（酸度上昇作用）の如何なる ものがら知られる。即ち，玄米が卓効を 奏するのは，この三作用の合力によるも のと考えられる。

5）最近重症脚気患者が殆見られなくなつ た事実は，V・B $\mathrm{B}_{1}$ 思想が普及したばかりで なく，其の外に，次の事柄がより大きな 原因であろうと考えられる。即ち，昭和 に入つてからの我国民は，明治・大正時 代に比べて，砂糖や脂肪の攝取量が增加 しこれによつて腸管內の酸度の上昇を 
来し, 大腸菌属の繁殖を不良ならしめて をる。のみならす，砂桾や脂肪の攝取の 為に第 II 含水炭素 ( (澱粉) 攝取量も減す。 る結果になり，䙲々，毒物商生の条件を 不良ならしめてをる。この㥞に考光られ る。更に，太平洋戦爭に入つて以后，戦 後の数年までに亘り，朋気患者及び乳児 脚気症を見ることか啮来なかつたのは， 次の如く考元られる。即ち, 戦時中及び その後当分の閖の 我国々民の食量は小で あり，然も，飞の小量なる主食第II 含水 炭素は粶成分含有の七分㨶兆であり，こ れに加うるに，主食补助として甘藷の如 き繊維を含有し，且つ，第 1 含水炭素を 含有し，醴酵を起して酸度の上昇を来す 性質のものをもつて补われてをるのであ るから，毒源も造毒条体も洪に低下して 来たものと孝えられる.今日白米飯を不 自由なく攝取し得る者の間に於いて, 再 び脚気症を。見るに至つたのを見ても，こ の事が知られると思う。

\section{結語}

1）穀粉栄養障碍児に於て乳児脚気様症状 を是する者（所謂穀粉養障碍症の乳児脚気型） の食慨を量的・質的に精查した結果，次の三 条件のある事を知つた。

(1) 所謂第 II 含水炭素の大量攝取

(2) 所謂第 I 含水炭素の 攝取量の極放て小 さなる事

(3) $\mathrm{V} \cdot \mathrm{B}_{1}$ が零ならざる事

2) 精白々米糊加無蛋白合成培地に Colicommunior, Coli-communis を培䓹し，そ の無菌滤液をマウスに注射した所，次の結果 を得た。培地の $\mathrm{pH}$ がアルカリ性に傾いてを り, 且つ, 培養日数が長ければ長い程, その 培食液中にはマウスを麻痺せしめ，その心藏 を肥大せしめる毒物がより多く含たれて居る。 然し他の球菌類では斯る毒物の產生がない。
3）精白々米糊を加えざる単なる無蛋白 合成培地に於ては，Coli-communior, Colicommunis と踓も，刎論，毒產生が見られな かつた。

4）この毒物は肝に於て或る程度解毒され るけれとも， $\mathrm{V} \cdot \mathrm{B}_{1}$ によつて直接的により强 く中和せられるものと理解 せられる成績を得 た。

5）脚気の本態は次の如く考えられる。䊏 白測粉偏食者（背白澱粉偏食によつて腸內酸 度の低下を来たし，大腸菌属の貹殖を来して をる者）に於て，若しその攝取㱖粉量が消化 力を越えて未涞分解停滯する時には，この未分 解糊状沜粉を培地として, Coli-communior, Coli-communis が一䠅の㻏物を產生する。 この毒物か：腸管から吸收せられて起る中等か; 脚気症であり，V·B $\mathrm{B}_{1}$ はこの中毒に対する中和 作用物である様に考えられる。

本論文の恐旨は第 56 回，第57 回，第58 回 日本小兒科学会総会及び第 1 回民族徫生学会福 島支部地方会に於て発表した。

\section{文献}

1) Baelz, E.: Mitteil. De_tsch. Gesel. Natür-Volker Kr. Ost 27. (1882)

2）青山：東京医学会雑誌，12,9.(明31)

3) 三浦 (檴)： Beriberi. Süpplement zü Nothnagels spezille Pathologie ü Therapie 103. (1913)

4）緒方(正)：中外医事·新報，121，1；122, 10. 123, 4；(明 18)

5）都留：細菌学雑誌，121，26；135, 133. (明 38)

6) 岡田他：陵軍々医学雑誌，144, 633.（明 38)

7) 葐垣: 台湾医学雑誌, 85, 623. (明 42)

8）田中：東京医事新誌，No.1634, 1935.（明 42) 
9）樋口：細菌学雑誌，350，269.（大 15）

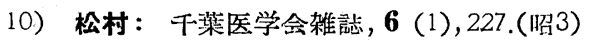
7 (12), 1530. (嚁 4) 9 (12), 133. (柖 6) 24 (1), 32. (雒 23)

: 医学通信, 89, 3. (炤 22)

11) 岡本: 細菌学雑点, 399, 400. (昭 4)

12）松川：自然, 5 (10), 9. (沿 25) ビタミン，2，174. (昭 25)

13）榊：医界時報, 561, 262; 562, 285; 563. $304 ; 565,364$. (明 38)

14）三浦(守)：東京医学会雑誌， 3, 21, 3, 22, (明 22)

15）長與：日新医学, 2, (1) 1. (明 45)

16）亳洲：兒科雑誌，40, 32. (明 36)

17）山極：東京医事新誌 No.1387, 2125. (明 37)

18）緒方(知)：日新医学, 13, 286, 413, 549 （大 14）

19) 河本：東京医事新誌，No.1030,1.(明31)

20) 弘田：兒科雑誌， 40, 74.（明 36)

21）三宅：医事公論， 1542, 539. (㽞 17)

22）寺尾：アレルギー畤報，8(6)，240.（咱 17)

23) 照内：日本內科学会雑誌, 17 (3), 345. 349. (㧽 4) 17 (6), 493. (沿 4) 18 (7), 706. (骝 5) 18 (9), 864. (炤 5) 19 (8), 971. (品 6) 20 (7), 874. (畛7) 21 (5), 767. (昭 8)

24）岡崎：医事新開，816, 1521. (明 43)

25）後滕：医学中央雑誌， 16, 251.338. (大 7)

26）佐苼：第58回 日本小兒科学会総会特別 講演，炤 29,5

27) C. Eijkman: Arch. Hyg. 58, 150. (19 06)

28）岛甶：脚気，克誠堂（炤 4)

29）大森：日本內科学会雑誌，21 (2)，468. (昭 8)

30) 林：日新医学, 3 (8), 1265. (大 3)

31）高洲他：阪大医学会雑誋，4 (12), 1157. (明 38)

32）黑田：彭断飞治㽷, 24(12), 1672. (炤 12)

33）大榡：日本之医界，18，86，17.（昭 3)
34) 池田： The Tokoku J. of Exp. Med., 53 (1\&2), 161. (1950)

35）池田：医界週報，388，1449.（炤 17)

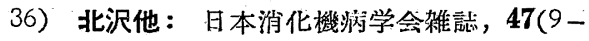
10), 21. (贻 25)

37) Najjar, Holt: J.A.M.A., 123, 683. (19 43)

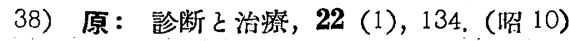

39）箕田：九大同門会々報，60, 57.（明 14）

40）赤坂：果京医事新誌，No.3063, 3285. (哕 12)

41）沼崎：東京医学会雑誌，27，3（大 ）

42）谷口：兒科雑誌, 391, 2292. (大 7)

43) 吳他: 実驗医報, 3, 25, 5.（大 5).

44）池田：第 2 回果北医学協会医学大会特別 㩐演, 炤 $22,1.1$

45）三宅：兒科雑誌，111，519.(明 42)

46）長沢：兒科雑誌，331, 2084。（炤 2)

47）太田：兒科雑誌，354，1861。（哚 4)

48）永井：兒科雑誌，354，1867。（欩 4)

49) 山本：兒科雑誌，358, 486。(炤 5) 360, 882. (哕 5)

50）泉田：兒科雑誌，381，367. (炤 7)

51）大森他： 兒科雑点, 415,1730. (昭 9)

52）幸田：兒科雑誌，426，645。（沿 10) 43 (3)，349. (炤 12)

53）佐々木：臨牀小兒科雑誌, 8 (12), 1146. (炤9)

54）渡辺：兒科雑誌，420，746.（炤 10)

55）鈴木：ピタミン，(第 3 版）日本評論社， 197. (炤 21)

56）吉川：日本消化機病学会雑誌，50(12), (補䢐 2) 10. (沿 28)

57) 岡本：臣応医学, 9 (5), 917. (㫟 4)

58）岩崎：医事公論，946, 14.（骂 5)，東京 医学全雑誌 $48(3), 1 ; 7$. (炤 9)

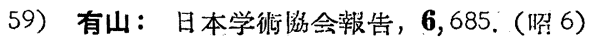

60）塩沢：東京医事.新誌，No.2752, 2599. (沿 6); No.2753, 2660. (昭 6)

61）矢野：兒科雑誌, 285, 1217. (骂 7)

62）衣川：満鮮の医界, 137, 1. (炤 7)

63) 橋本: 满洲医学学雑誌, 17 (2), 307. (昭 7)

64）大野：兒科雑誌，401, 805.（炤 8)

65）坂本：医事公論，947，14. (炤 5)

66） 入山: 関西医事, 373，3. (嚁 13)

374, 3. (㗁 13) 


\section{CHANGES IN POSTURAL BLOOD PRESSURE REFLEX WITH ADVANCING AGE}

By

Mitio Ikai, Hiroshi Furuhata and Jun'ko Yamakawa

The postural blood pressure reflex after a change of posture has been studied by Prof. K. Hukuda and his associates. It has been revealed by them that the pattern of the postural blood pressure reflex was modified by fatigue and constitution of individuals. The present authors studied the change of various measures on the postural blood pressure reflex in healthy Japanese males and females ranging in ages from six to fifty-four years. The time for restoration of the brachial blood pressure after the change of posture decreases with age up to forties, while it increases somewhat above fifty. The irregular undulation of the blood pressure in the time course of restoration is more marked in children and the aged than adults. There was found no difference between males and females in the reflex pattern. It is revealed from the results that adjustment of the blood pressure to the postural change developed with advancing age up to forties but began to fail over fifty.

(From the Department of Physiology, University of Tokyo Medical School)

\section{FURTHER STUDY ON ETIOLOGY OF BERIBERI}

By

R. Ikeda and T. Tokutomi

1. Infants with nutritional disturbance due to rice flour feeding were studied from the viewpoint of etiology of beriberi. As the result it became clear that those infants showing the symptoms of infantile beriberi had taken (i) a great quantity of so-called secondary carbohydrates, (ii) an extremely small quantity of primary carbohydrates i. $e$. sugars, and (iii) some quantity of vitamin $B_{1}$.

2. Coli communior and Coli communis were cultured on protein-free media added with polished rice paste, and bacteria-free filtrate of the culture was found virulent to mice, when the $\mathrm{pH}$ of the media was on the alkaline side. Paralysis and heart dilation were observed in the mice injected with such culture filtrate. The effect was proportional to the duration of the culture. Cocci did not produce such poisonous material.

3. Similar cultures obtained without addition of polishod rice paste did not produce such poison.

4. This poison was detoxicated by the liver to a certain extent. There were evidences that suggest vitamin $B_{1}$ is a powerful detoxicating agent for this poison.

5. A working hypothesis of the authors on the nature of beriberi is formulated as follows :

Unbalanced habitual eating of polished rice starch lowers the acidity of the intestinal 
content which allows proliferation of Coli group. When excessive amount of starch is taken in such individuals, it cannot be hydrolysed away, and the stagnant starch may represent suitable media for Coli communior or Coli communis to prodce a certain poisonous subtance, which, absorbed across the intestinal wall, causes beriberi. Antiberiberic action of vitamin $B_{1}$ consists in detoxication.

Briefly, the authors regard the beriberi as a intoxication instead of a deficiency disease.

(From the Department of Pediatrics, Fukushima Prefectural School of Medicine).

\section{SPECIAL FEATURE IN MENTAL WORK OF A COLLEGE GIRL WITH A HISTORY OF THUNDER-STROKE}

By

Kunizo Hukuda and Yoshiko Yamanouchi

1. This is a report of mental work testing on a college girl, who had previously, 20 months before, been struck unconscious by thunder. At that time she, a rural high school student, was riding a bicycle on a country road.

2. Her result is on a high level on the whole; but marked fatiguabiliy is noticed in the course of the test, which was carried out on the principle of Kraepelin and in the procedure developed in Japan by Mr. Uchida.

3. This special feature was more manifest in the author' clock-signaled session than in the conventional human-signaled session. The former means time-signaling with a specially adapted signal clock, while, in ordinary procedure of the Kraepelin-Uchida's mental work test, the time is signaled to the subjects under test by the supervisor of the testing.

4. Clock-signaling is recommended as more advantageous than conventional humansignaling, so far as the former contributes to eliminating the possible effect of situation influenced by the human relation.

5. Mental work curve or the scores of the speed of simple addition, recorded minute by minute and plotted as ordinates against time, shows inevitable fluctuation. The authors proposed a way of smoothing out the curve or rather of attenuating the fluctuation. A new concept of degree of fluctuation was also defined.

(From the Division of Health-Care and Nursing, University of Tokyo Medical School and Hiroshima Junior College for Women). 